\title{
Occupational exposure to uncomfortable temperatures in two university presses of Costa Rica
}

\author{
Lourdes Arce Espinoza ${ }^{1} \&$ Julián Monge Nájera² \\ ${ }^{1}$ Servicio Médico, Universidad Estatal a Distancia, 474-2050 San Pedro, Montes de Oca, San José, Costa Rica; larce@uned.ac.cr \\ ${ }^{2}$ Vicerrectoría de Investigación, Universidad Estatal a Distancia, 474-2050 San Pedro, Montes de Oca, San José, Costa Rica; julianmonge@gmail.com
}

Recibido 16-X-2010 Corregido 24-I-2011 Aceptado 31-I-2011

\begin{abstract}
Many industrial processes are carried out under conditions of high temperatures, creating discomfort among workers, and less frequently, a health risk, especially when heat is combined with poor ventilation and a lack of medical supervision. This problem has seldom been studied in Latin America, so this study measured the occupational exposure to overheating in workstations from the printing shops of two university publishers in a tropical city (San José, Costa Rica). We measured heat conditions in 55 workstations using a thermo-anemometer and a heat stress meter, both calibrated and certified. Workers use the workstations during the day but have several interruptions and we concluded that, even though there is a high percentage of dissatisfaction among workers regarding the temperature (50\% to $80 \%)$, there is no risk of heat stress. To reduce the reported level of discomfort, we recommend that new workers be allowed an acclimation period and modification of rooms to allow more natural ventilation. Similar studies are needed in other Latin American countries, if our data are to be compared in a meaningful way.
\end{abstract}

\section{KEY WORDS}

Occupational health, heat stress, thermal comfort, occupational exposure to high temperatures.

\section{RESUMEN}

Muchos procesos industriales se llevan a cabo en condiciones de temperatura excesiva, creando en la mayoría de los casos malestar $y$, con menor frecuencia, un riesgo para la salud, especialmente cuando se añaden al calor una ventilación inadecuada y la falta de supervisión médica. Este problema ha sido estudiado pocas veces en América Latina, por lo que evaluamos la exposición laboral a temperaturas elevadas de los trabajadores en las imprentas de dos editoriales universitarias de San José, Costa Rica. Medimos el nivel de calor en 55 estaciones de trabajo, usando un termo-anemómetro y un medidor de estrés térmico, ambos calibrados y certificados. Aunque no hallamos peligro de estrés térmico, $50 \%$ a $80 \%$ de los trabajadores indicaron insatisfacción con la temperatura de sus estaciones de trabajo, por lo que recomendamos que a los nuevos trabajadores se les permita un período de aclimatación previa y mejorar la ventilación de las instalaciones. Se necesitan estudios similares en otros países de América Latina para que los datos obtenidos puedan ser comparados.

\section{PALABRAS CLAVE}

Salud ocupacional, estrés térmico, comodidad térmica, exposición ocupacional a altas temperaturas.
Working conditions are determined in part by physical factors that can cause discomfort among workers. In many industries, heat is among the main complaints, and health care personnel needs to know whether it is just a matter of discomfort or a full health risk (Barrios-Casas \& Paravic-Klijn 2006). High heat levels are a particularly serious public health threat for the elderly and persons with pre-existing health conditions (Richard et al. 2011). The problem also affects children even in countries where large amounts are spent in their well being, for example, in school buildings (Jenkins et al. 2009).

Exposure to excessive heat also has a negative impact on productivity, even in acclimatized individuals, and the symptoms include increased heart rate and excessive sweating or lack of it, sometimes leading to medical emergencies such as heat exhaustion, heat stroke and heat stress. Other health conditions that can develop from heat include rashes, cramps, dehydration, discomfort, apathy, memory loss and worsening of chronic diseases 
(Parra 2003, Suárez 2006, Bertoldi et al. 2007, Toscani 2007, Caballero \& Suarez 2009, Ro-Ting \& Chang-Chuan 2009).

The high temperature and humidity levels that are frequent in tropical cities, added to the vigorous physical activity of traditional printer shops and the use of protective equipment, make exposure to high temperatures more frequent, and therefore more difficult to control, in large parts of Latin America (Almirall et al. 2006). These conditions are expected to worsen because of the current global warming. In recent years, the study of working conditions has led to a decrease in hazardous or unsafe exposures in places like Colombia, for example (Instituto Nacional de Seguros de Costa Rica 1997, Coneo-Mendoza \& Donado-Arias 2009). However, little has been published on this subject in Latin America (Rocha et al. 2010), and to our knowledge, nothing is known about the working conditions in the print shops of any university, so our study contributes to a poorly known subject that will become more important because of global warming. Even in temperate countries, climate change increases potential threats to comfort and health. For example, in Britain, during a hot period, more than $40 \%$ of bedrooms failed the recommended overheating criteria (Mavrogianni et al. 2010). A study that used dynamic computer simulation with defined domestic building variants found that even with a window-opening schedule, the average internal temperature in Europe could be over $28^{\circ} \mathrm{C}$ for almost $12 \%$ of the year and that with climate change there will be cooling problems in bedroom areas for approximately a third of the year (Peacock et al. 2010).

The study was done as part of an overall analysis of working conditions. We are certain that this is the first study on the levels of exposure to high temperatures of the staff of university publishers in Costa Rica.

\section{METHODOLOGY}

\section{Subjects}

We evaluated the workstations in two university presses in San José, Costa Rica (total: 55 workstations). The facilities do not exceed $400 \mathrm{~m}^{2}$ each and only have small windows that cannot be opened.

\section{Methods}

We chose the printing buildings because they have heavy industrial machinery that emits heat and because their buildings have little air circulation. Furthermore, our experience is that this type of work requires a higher metabolic rate than office work.
We made heat measurements in the hottest time of the year (March 5 through April 15, 2010), during the hottest part of the day (11-14 hr), because we were looking for a possible problem of over-heating. The city never reaches significantly low temperatures so we did not study the periods with low temperatures.

Institution 1 has 20 workstations and Institution 2 has 27 workstation in one building (offset printers) and 8 workstations in another building (digital printing machine).

We set 20 measuring points in Institution 1 and 35 points in Institution 2 and made 20 measurements per day at each point. We used an Extech HD300 ThermoAnemometer and an Extech HT30 Heat Stress Meter; both instruments were calibrated and certified. We measured dry and wet temperatures, balloon temperature, relative humidity, and wind speed.

We labeled measurements according to the following standards that are official for Costa Rica (see References for details about their methods and symbology):

1. NTP 18: Heat Stress: Assessment of Intense Exposure

2. NTP 322: "WBGT Assessment of Heat Stress Risk"

3. INSTITUTO NACIONAL DE SEGUROS DE COSTA RICA 1997 31-08-09-97 Exposure to Heat Stress Environments

4. NTP 74:Thermal Comfort Evaluation, Fanger Method

\section{Ethics}

We followed all pertinent ethical guidelines described by Emanuel et al. (2000). Our study provides original and rigorously collected scientific information on a previously unknown subject; the results can be used to improve health care in the studied institutions and similar environments and no individual identities are presented or can be identified. Furthermore, the University Research Division, which includes ethics among its criteria, approved the project and no medical treatment was applied: in fact, we studied workstations, not humans.

\section{RESULTS}

We present the results in $\mathrm{kcal} / \mathrm{hr}$, which is not an IS unit, because it is the one currently in use in Costa Rica for this kind of standards.

The average metabolism value is $186 \mathrm{kcal} /$ hour in both institutions. The temperature allowed by the above-cited standards under these conditions is $30^{\circ} \mathrm{C}$. We recorded a mean of $27,7^{\circ} \mathrm{C}$ in Institution 1 and of $29,0^{\circ} \mathrm{C}$ in Institution 2 
(Table 1), so there mean temperatures are close to the limit but do not exceed it.

The temperature dissatisfaction levels (Table 2 ) indicate that $70 \%$ of the workers are dissatisfied with the heat in Institution 1 and $80 \%$ are dissatisfied in Institution 2.

\section{DISCUSSION}

Even in temperate countries, overheating is periodically a threat to the comfort, health and even life of millions of people (Mavrogianni et al. 2010), and the problem is even greater in the naturally hot tropical regions of the world. However, and in contrast with many other tropical cities, San José has a mild climate, ranging from $17^{\circ} \mathrm{C}$ to $26^{\circ} \mathrm{C}$ most of the year (Instituto Meteorológico Nacional de Costa Rica 2011). For this reason, workers are not exposed to the extreme levels of overheating that can be found even as close as in Panama City and Managua.
At a metabolic value under $200 \mathrm{kcal} / \mathrm{hour}$, there is no risk of heat stress, but workers are exposed to more than the optimal temperature for development of any activity which is $22^{\circ} \mathrm{C}$ (Organización Internacional del Trabajo 2005). However, a slight increase in metabolic load, at the temperatures we measured in these workstations, would lead to heat stress (Instituto Nacional de Seguros de Costa Rica 1997, 2001, Parra 2003, Suárez 2006, Toscani 2007). Sustained overheating can lead to heat syncope, cramps, heat exhaustion, heat stroke and dehydration (Instituto Nacional de Seguros de Costa Rica 1997 Standard 31-08-09-1997, Bertoldi et al. 2007, Ro-Ting \& Chang-Chuan 2009).

The Fanger values are extremely high, reaching 80\%: they should not exceed 5\% (Instituto Nacional de Seguridad e Higiene en el Trabajo 2000). Our results could be evaluated with the ISO 7730 norms (International Standards Organization 2005 ) as well as with the Fanger Method, but we used the second. The Fanger Method was proposed in 1973 to evaluate thermal comfort, and it

TABLE 1

Temperatures $\left({ }^{\circ} \mathrm{C}\right)$ in two university presses of San José city, Costa Rica (2010)

\begin{tabular}{lcccc}
\hline & Mean & $\begin{array}{c}\text { Standard } \\
\text { Deviation }\end{array}$ & Minimum & Maximum \\
\hline Institution 1 & 27,7 & 1,65 & 23,4 & 30,7 \\
$\begin{array}{l}\text { Institution 2, offset } \\
\text { building }\end{array}$ & 29,0 & 1,62 & 21,6 & 31,7 \\
$\begin{array}{l}\text { Institution 2, digital } \\
\text { printing building }\end{array}$ & 26,1 & 0,84 & 24,8 & 29,9
\end{tabular}

TABLE 2

Calculation of Fanger temperature dissatisfaction levels in two university presses of San José city, Costa Rica (2010)

\begin{tabular}{ll}
\hline \multicolumn{1}{c}{ Institution 1 } & \multicolumn{1}{c}{ Institution 2 } \\
\hline Lower temperature & Lower temperature \\
$\mathrm{TRM}=\mathrm{TG}+1,9 \sqrt{\mathrm{v}}(\mathrm{TG}-\mathrm{TS})=25,4$ & $\mathrm{TRM}=\mathrm{TG}+1,9 \sqrt{\mathrm{v}}(\mathrm{TG}-\mathrm{TS})=29,3$ \\
$\mathrm{IVM}=1,55+0,08(25,4-23,4)=1,7$ & $\mathrm{IVM}=1,55+0,08(29,3-24,8)=1,9$ \\
& \\
Higher temperature & Higher temperature \\
$\mathrm{TRM}=\mathrm{TG}+1,9 \sqrt{\mathrm{v}}(\mathrm{TG}-\mathrm{TS})=34,1$ & $\mathrm{TRM}=\mathrm{TG}+1,9 \sqrt{\mathrm{v}}(\mathrm{TG}-\mathrm{TS})=34,7$ \\
$\mathrm{IVM}=1,55+0,08(34,1-30,7)=1,8$ & $\mathrm{IVM}=1,55+0,08(34,7-29,9)=1,9$
\end{tabular}

NOTE: The data indicated a slight risk of heat stress, so we calculated heat dissatisfaction levels with the Fanger Method (without any correction factor because the relative humidity was 50\%), which is the current method in Costa Rica. For the meaning of equations see Instituto Nacional de Seguridad e Higiene en el Trabajo (2000 and 2001a,b). 
takes into account clothing, metabolic rate, radiant temperature and relative humidity. Even though the method is not new, we used it instead of the ISO 7730 because it is the method used in Costa Rica, where we made the study (Instituto Nacional de Seguros de Costa Rica 1997).

From our results with this method, it is clear that even though not exposed to dangerous overheating, the staff that uses these workstations suffer from heat discomfort. The laborers work half hour shifts with the workstations and do complementary work away from the workstations every other half hour. Work consists mainly of placing books on particular machines, cutting and binding paper, and checking for faulty copies. It is a repetitive work that includes lifting light weights. The work is lighter in the colder and quiet digital pressroom, while the other rooms use older, offset machinery and are more noisy and hot, making the whole operation uncomfortable and stressing after some time. The elderly and people with pre-existing health conditions need specially careful protection from excessive heat (Richard et al. 2011). In the two institutions that we studied, the staff is composed mainly of middleaged men. Women and elderly workers are few, but in 1520 years most of the staff using these workstations will be elderly workers and thus they will be more susceptible to problems associated with overheating. If the equipment is updated before that, the potential problem will be reduced, but considering the financial situation of these and other Latin American public universities, the update is unlikely to take place.

\section{RECOMMENDATIONS}

We recommend remodeling the three buildings to increase natural ventilation to reduce the levels of discomfort reported by the users of these workstations. Adding external shading can also reduce overheating significantly, especially if combined with a window-opening schedule (Jenkins et al. 2009, Peacock et al. 2010).

Furthermore, we suggest that new workers be allowed an acclimation period before starting the part of the work that consists of weight lifting and repetitive movements.

Similar studies are needed in other Latin American countries, if our data are to be compared in a meaningful way.

\section{ACKNOWLEDGMENTS}

We thank the staff of both institutions for their cooperation during data collection, Andrea Sánchez Guevara, for her assistance, and two anonymous reviewers whose comments led to greatly improving the article.

\section{REFERENCES}

Almirall, P. J., W. Dieste, N. del Castillo, J. S. Hernández, A. González \& C. Parada. 2006. Calor y efectos negativos del trabajo. Un enfoque ergonómico. Revista Cubana de Salud y Trabajo 7: 40-49.

Barrios-Casas, S. \& T. Paravic-Klijn. 2006. Promoción de la salud y un entorno laboral saludable. Revista Latino-Americana de Enfermagem 14: 136-141.

Bertoldi, C., P. Medeiros, R. Pacheco, G. do Nascimento \& S. Pacheco. 2007. Condiciones de trabajo en la producción de comidas como factores de riesgo para la enfermedad venosa de miembros inferiores. Medicina y Seguridad del Trabajo 53: 25-32.

Caballero, E. \& R. Suárez. 2009. Tensión fisiológica por exposición laboral a ambientes calurosos en trabajadores de cocina. Revista Cubana de Salud y Trabajo 10: 21-9.

Coneo-Mendoza, Y. \& S. Donado-Arias. 2009. Accidentes de trabajo y productividad laboral: dinámica, determinantes e impacto en el gremio de la ANDI seccional Cartagena durante el año 2006. Panorama Económico 16: 119-144.

Emanuel, E.J., D. Wendler \& C. Grady. 2000. What Makes Clinical Research Ethical? Journal of the American Medical Association. 283: 2701-2711.

Instituto Meteorológico Nacional. 2011. Estado actual del tiempo. (http://www.imn.ac.cr/; downloaded January 23, 2011)

Instituto Nacional de Seguridad e Higiene en el Trabajo. 2000. Norma Técnica 74: Comfort Térmico. Método de Fanger para su evaluación. Madrid, España.

Instituto Nacional de Seguridad e Higiene en el Trabajo. 2001a. Norma Técnica 18: Estrés térmico. Evaluación de las exposiciones muy intensas. Madrid, España.

Instituto Nacional de Seguridad e Higiene en el Trabajo. 2001b. Norma Técnica 322: Valoración del riesgo de estrés térmico, índice de WBGT. Madrid, España.

Instituto Nacional de Seguros de Costa Rica. 1997. Norma INTECO 31-08-09-97. Exposición a ambientes con sobrecarga térmica. Límites máximos permisibles. Madrid, España.

International Standards Organization. 2005. ISO 7730: Ergonomics of the thermal environment -- Analytical determination and interpretation of thermal comfort using calculation of the PMV and PPD indices and local thermal comfort criteria. International Standards Organization, Geneva, Switzerland.

Jenkins, D., A. Peacock \& P. Banfilla. 2009. Will future low-carbon schools in the UK have an overheating problem? Building and Environment 44: 490-501.

Mavrogianni, A., M. Davies, P. Wilkinson \& A. Pathan. 2010. London housing and climate change: Impact on Comfort and Health - Preliminary Results of a Summer Overheating Study. Open House International 35: 49-59.

Organización Internacional de Trabajo (OIT). 2005. Calor y frío. Enciclopedia de salud y seguridad en el trabajo, OIT, Madrid. 
Parra, M. 2003. Conceptos básicos en salud laboral. Organización Internacional del Trabajo, Santiago, Chile. 31 p. (http:// www.oitchile.cl/pdf/publicaciones/ser/ser009.pdf; downloaded January 7, 2011)

Peacock, A., D. Jenkins \& D. Kanea. 2010. Investigating the potential of overheating in UK dwellings as a consequence of extant climate change. Energy Police 38: 3277-3288.

Richard, L., T. Kosatsky \& A. Renouf. 2011. Correlates of hot day air-conditioning use among middle-aged and older adults with chronic heart and lung diseases: the role of health beliefs and cues to action. Health Education Research 26: 77-88.
Rocha, F.L.R., M.H.P Marziale \& Oi-Saeng Hong. 2010. Work and health conditions of sugar cane workers in Brazil. Revista da Escola de Enfermagem da USP 4: 974-979.

Ro-Ting, L. \& C. Chang-Chuan. 2009. Efectos del calor sobre la salud y la productividad de los trabajadores en Taiwan. Cuadernos Médicos Sociales 49: 278-279.

Suárez, E.L. 2006. Estrés térmico y su impacto en la efectividad y confort de los trabajadores. Evaluación ambiental. Revista Cubana de Salud y Trabajo 7: 63-65.

Toscani, D. 2007. El microclima laboral. Su influencia en los trabajadores. Gestión práctica de riesgos laborales: Integración y desarrollo de la gestión de la prevención 42: 48-54.

Article edited by Vanessa Nielsen 
